\title{
The concept of violence in the philosophy of Aristotle
}

\author{
Sergei Borisov, Viktor Rimsky*, Roman Ivashina, Igor Lyashenko \\ Belgorod State National Research University, 308015, Belgorod, Russia
}

\begin{abstract}
The idea that the concept of 'violence' was part and is still viewed as part of a broad philosophical category may seem strange. However, the problem is resolved by referring to the concept of 'force,' which is lost in modern philosophy. The exception was the works in which we find some "traces" of this concept, including the works of Aristotle, which need to be free from modernizing interpretations. Still, in the

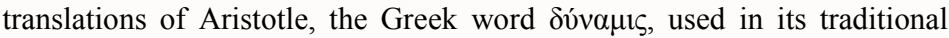
meaning of potentiality, lost its connotations of force (movement, capability, function); in turn, 'force' was no longer linked with 'violence' $(\beta 1 \alpha)$ and 'necessity.' Violence is seen as a kind of necessity, which is associated with the suppression of 'will,' freedom, something 'frustrating desire' and contrary to 'common sense,' as well as the absence of 'good.' Violence is presented not only in an ontological sense, but also existentially, as the opposite of 'good' and one's own 'desire.' Force stays in the background of 'necessity' as 'potentiality', 'potential energy' and 'movement', and violence loses the opposition that has arisen in the ontological mode.
\end{abstract}

\section{Introduction}

Initially, we turned to the hermeneutics of the texts of Aristotle in the existing Russian translations, trying to give our own understanding of violence in the modern philosophical context in view of its categorical inadequacy. Philosophical categorization presupposes the primary definition of an interpretable phenomenon, but the existing conceptual forms turned out to be "insufficient" and left a certain "gap" between the phenomenon and the notion 'violence', giving rise to an obvious semantic and conceptual uncertainty in understanding violence.

We intuitively regarded the studied categorical links 'man - violence', 'violence - being', 'violence - non-violence' as implicitly belonging to the historical and philosophical categorical context. Not only in domestic, but also in Western public (and scientific!) discourse, the problematic field of violence was loaded, above all, with political and ethical meanings and senses - political apology or ethical criticism of violence.

We tried to draw upon the meanings of the native, Russian language, but even here it was found that in everyday usage the term 'violence' often carries a "negative connotation", but it does not exhaust language meanings - in living and historical languages everything is

*Corresponding author: rimskiy@bsu.edu.ru 
more complicated. In "The Explanatory Dictionary of the Living Great Russian Language" by Vladimir Dahl we can find the meaning of such terms as 'насилить' (to violate), 'насиловать' (to force oneself on sb), 'насиливать' (to do violence to), which suggest the following meanings: to enforce, to constrain, to compel to something by force, to coerce. There are also terms 'насилие' (violence) and 'насильство' (coercion) used in the following meanings: compulsion, bondage, need of force, restraining action, insulting, illegal and willful action. There are some more meanings: arbitrariness, life under oppression, to control or keep in submission with force (violence) [11, p. 1218]. We singled out the meanings that already initially contain certain intuitive philosophical connotations. First, it is obvious that negative meanings do not prevail here. Secondly, the meaning of 'compulsion' and 'un/freedom' (bondage) is retained. Thirdly, there appears a connection with everyday resentment and 'constraint', 'illegality' and 'domination' (life under oppression), and, finally, with pragmatic governance. As we see, the Russian language, "the great and mighty" as "the house of being" (Heidegger), contains many hidden meanings, and at the same time opens up large space for our categorization.

We would like to give a hermeneutic understanding of force and violence in the context of Aristotle's philosophy, and, above all, to dwell on the "Russian Aristotle," or rather, the Russian reading of Aristotle (mentioned by colleagues from St. Petersburg), to which young V.V. Rozanov contributed after the publication of his treatise "On Understanding", which has not yet been recognized as hermeneutic and still remains unappreciated. In his letter to N.N. Strakhov on February 15, 1888, V.V. Rozanov writes: "For about two years, while getting acquainted with various works..., more and more I became convinced, or rather, had a hunch that the root of the matter, the key to the resolution of many questions, which for me means to live or die, is in Aristotle" [10, p. 153]. In his letters, N.N. Strakhov expressed some skepticism about the Russian relevance and topicality of Aristotle, although he appreciated Rozanov's translation, perceiving it as a kind of cultural act, and proposed his personal assistance in its publication. Still, in his comments of 1913 to the letter of 23 February, 1888 from N.N. Strakhov, as if continuing their dispute, V.V. Rozanov notes: "I am still convinced that Aristotle remains indispensable" [10, p. 9].

In these comments we can find a rather remarkable idea of V.V. Rozanov about the place of 'dynamis' and 'energy' in Aristotle's categorical series: “... the concepts of $\delta v v \alpha \mu 1 \varsigma$ and $\varepsilon v \varepsilon \dot{\varepsilon} \rho \varepsilon i \alpha$ in their Latin terms potentia and actus (I only don't really understand actus; in my work I have always talked about potentiality and actuality; actually, in my work it means a 'forming existence', but we did not get to this in "Met") serve as a key to understanding the most complex and profound systems of philosophy. In them, as in mysterious symbols, the whole system of thought is expressed, and this and that have become clear (change is the main thing) ..." [10, p. 154]. And in the next letter of March 2, 1888, about his translation and interpretation of Aristotle, he continued his thought: "I want to familiarize myself with it in order to find out more about his conceptions of potentiality (this is the most important thing), which he first introduced into philosophy and probably well elaborated" [10, p. 160]. No one has yet truly appreciated this Rozanov's hermeneutics of Aristotle's "Metaphysics", although it is very important, in particular for understanding the ancient meanings of the phenomenon of violence.

Therefore, we were surprised by the new translations of Aristotle, which reduce the inflectedness of the ancient Greek language, which is cognate to Russian and German, to a primitive modernizing analyticity. Thus, for example, A.V. Markov quite consciously not

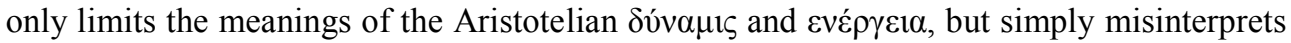
them, as well as some other categories: "Therefore, let the reader not be surprised that I often translate 'logos' as 'formula' (and rarely 'proportion', Kubitsky often uses 'definition'), 'atom' as 'individual', 'genesis' as 'production', several times I describe 'art' as 'cooking', I translate 'energy' simply and solely as 'actuality', and, following the Russian poets and 
prosaist of the XX century, I prefer the word 'existence' to the word 'essence' [9 p. 8]. It is natural that Markov's translation of Aristotelian "Metaphysics" received a fair criticism of specialists [13, p.361-385]. Trying to supposedly update Aristotle's vocabulary and at the same time preserve his identity, as if bringing him closer to the languages of "Mandelstam and Pasternak, Platonov and Nabokov", A.V. Markov does not seem to know that it is impossible to combine the innovative language of Nabokov or the avant-garde language of Pasternak with the deliberately archaized style of Platonov or Mandelstam. In the same way, it is difficult to combine the actualization of the Aristotelian language with the restoration of its archaic primordial meanings.

M. Heidegger will speak and write about the actualizing reading of Aristotle with the simultaneous restoration of the original identity only about thirty-five years after V.V. Rozanov! Heidegger's "love for Aristotle" began early: at the time of his studies at the theological faculty. But it was in his lectures at the Faculty of Philosophy that he called on his students to turn to Aristotle from modernity and return to the ancient meanings of his concepts, which did not mean, however, a kind of modernization of ancient philosophy. It rather meant the archaization of modern (relevant) philosophy, the search through the restoration of the original meanings of a specific philosophical language that had been lost

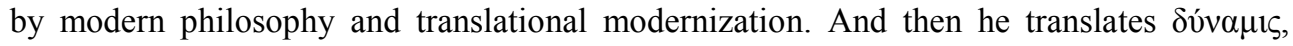
meaning in modern German Vermögen, Kraft, Fähigkeit (force, capability , potentiality), as das bestimmte Verfügenkönnen über; Bereitschaft zu ... (a certain ability to have control; readiness to...) [12, p. 210]. One may be surprised at the quirkiness of Heidegger's translations, but at the same time he was solving the mystifying tasks of constructing his adequate philosophical language through reading the thesaurus of the philosophy of antiquity, but he didn't impose modernizing meanings or avant-garde translations on the ancient vocabulary.

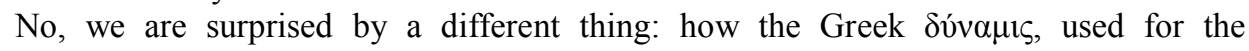
traditional delivery of the Aristotelian interpretation of the category of potentiality, lost its connotations of force (movement, capability, function); in turn, 'force' lost its link with 'violence' $(\beta 1 \alpha)$ and 'necessity'.

\section{Findings}

We believe that before referring to the categorization of violence in Aristotle's works one should start with the reading of the works "Physics" [3], "On the Heavens" [2] and "Metaphysics" [1], which were hardly read by anyone from this perspective [8]. Therefore, we are surprised by the new translations of Aristotle, which reduce the inflectedness of the ancient Greek language to a primitive modernizing analyticity [5]. So, for example, A.V.

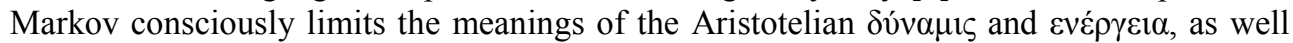

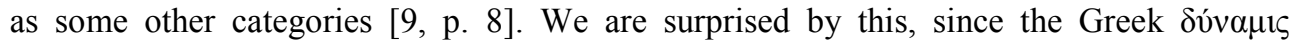
(dynamis), used for the traditional delivery of the Aristotelian interpretation of the category of potentiality, also contains connotations of force (movement, capability, function); in turn, 'force' as 'violence' $(\beta 1 \alpha)$ is linked with the category of necessity.

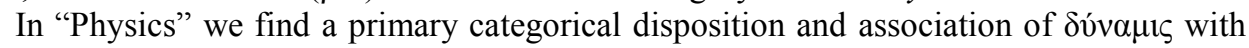
force and movement [3, p. 123-124, 219-220 and others]. The study of the treatises "On the

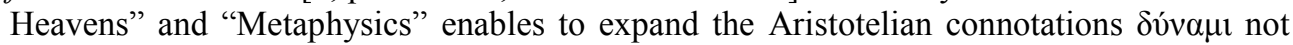

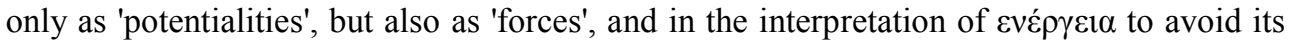
understanding as 'actuality', associating it both with 'action', 'necessity' and 'violence'. In his treatise "On the Heavens", Aristotle, criticizing the Pythagorean "String Theory", concludes that none of the "heavenly bodies" can move with the motion either of animate nature or of constraint, 'under compulsion'" [2, p. 323, 337]. Here force and violence are 
regarded in inseparable connection with 'naturalness' or, in Russian, 'естественность' (the natural), as well as 'necessity'.

But what senses does Aristotle implicate in 'violence' and 'constrained movement'? The movement 'of animate nature' obviously implies some kind of 'organicity', 'self-movement', but 'constraint' means 'unnaturalness' and 'compulsion' [2, p.345, 346]. But the Russian 'естественное' (the natural) carries the meaning of 'existence', 'being', 'something real', conversely, 'противоестественное' (the unnatural) means 'something that is not real', nonexistent, which clearly results in the negative attributes of violence, its belonging to the non-existent, non-being, destruction.

In this sense, unnaturalness is again linked with an action, some kind of activity or movement, whose nature is revealed when reading and interpreting "Metaphysics" [1, $\mathrm{p}$. 151]. Violence is understood here as such kind of necessity, which is associated with the suppression of freedom ('will'), something 'frustrating desire' ('realization of one's own will') and contradicts 'common sense', as well as the absence of 'good'. Violence appears not only as a 'necessity' in its ontological sense, but also existentially, as the opposite of 'good' and one's own 'desire'. And 'necessity' acts as fatal and inevitable, as the Goddess of Destiny or Destiny itself. Further, Aristotle (Book V, Chapter 12) [1, p. 162-164] regards 'suffering' in connection with 'capability' or 'potentiality' (dynamis) as a 'shortage', 'void' and lack of 'ability'. It is not clear why the translator here preferred to translate dynamis as 'potentiality', not 'force'. Force stays in the background of 'necessity' as 'potentiality', 'potential energy' and 'movement', and violence loses the opposition arisen in an ontological mode.

If we turn to "Metaphysics" in the translation of P.D. Pervov and V.V. Rozanov [4] and compare, we will see the substantiation of what we have already identified before (Book V, Chapter 12) [1, p. 163]: the concepts of 'destructive force', 'lack of ability', 'denial' are again closely linked with 'violence' as something that bears the non-existent, non-being and death. Again, there is a certain 'non-being', being minus something, but there is no violence as a characteristic of being, which is necessary not even as the second, but as the first in the categorical pair of force-violence.

These meanings and the need for 'force' in the transition from 'potentiality' to 'actuality' arise further in the book (Book IX, Chapter 1) [1, p. 234-236]. Aristotle himself refers to them [1, p. 162-164], but the translator again stubbornly does not use the word 'force', although Stagirit writes: "We have pointed out elsewhere that 'potentiality' and the word 'can' have several senses" [1, p. 234]. Whereas the word 'can' ('power') in Russian is 'force' (сила) ('to be able' (возмочь) and 'to overpower' (превозмочь) - to turn into actuality). With understanding of power as a "stronger" category of force, the dialectic of force and violence becomes apparent, which is revealed through the opposition of не/способность способность (in/capability - capability); не/силие - сила - на/силие (un/forced - forced violent).

\section{Research Method}

The study of the hermeneutic understanding of force and violence in the context of Aristotle's philosophy is based on analytical, synthetic, and comparative methods.

\section{Conclusion}

Thus, we can find all the meanings of interest in Aristotle's works, including the category dynamis which can be interpreted as force, and then 'force' as 'violence' $(\beta 1 \alpha)$ can be linked with the categories of potentiality and necessity. Potential force as a capability in the 
context of nature and necessity is placed in the context of naturalness - force and unnaturalness - violence as two equally possible sides of being. The unnatural nature is such a being, which is in need, and is linked with necessity as necessitation (compulsion), distortion of the real, natural good, or a kind of "seizure" of power. As a result, there is a collision of 'action' (energeia, force) with 'counter/action' (violence) as a clash between 'natural' or 'free' force and "usurped" power, i.e. violence as usurpation of 'will'.

Naturally, the "Russian interpretation" of Aristotle must be supplemented with new translations and actualizing interpretations similar to what V.V. Rozanov did in his time, and Heidegger did in the twenties of the last century, if it is really possible... Likewise, it should be supplied with a retrospective analysis of the Greek text through the use of a modern thesaurus, a "cloud" of today's senses, texts and authors. Thus, W. Benjamin, who has become popular today with his concept of 'divine violence', raises the question: is there something in the Aristotle's game of forces and potentialities that does not contain violence and is absolutely 'non-violent'?

And Aristotle answers him: "Now some things owe their necessity to something other than themselves; others do not, but are themselves the source of necessity in other things. Therefore the necessary in the primary and strict sense is the simple; for this does not admit of more states than one, so that it cannot even be in one state and also in another; for if it did it would already be in more than one. If, then, there are any things that are eternal and unmovable (God - auth.), nothing compulsory or against their nature (emphasis added) attaches to them" [1, p. 151-152]. Only God is not subject to violence as such necessary, which is the most 'simple', 'a simple force', 'a prime mover' and 'a prime cause': "And life also belongs to God; for the actuality of thought is life, and God is that actuality; and God's self-dependent actuality is life most good and eternal. We say therefore that God is a living being, eternal, most good, so that life and duration continuous and eternal belong to God; for this is God" [1, p. 310]. God as true being is non/violence absolute. There is one step to Walter Benjamin [7, p. 65-99] with his 'divine violence.'

\section{References}

1. Aristotle, Aristotle. Metaphysics, transl. from Greek by A. V. Kubitsky, ed. by M.I. Itkin, Aristotle. Writings. In 4 vol., Vol. 1., Moscow, Mysl. (1981 a). (in Russian).

2. Aristotle, Aristotle. On the Heavens, transl. by A. V. Lebedeva, Aristotle. Writings. In 4 vol., Vol. 3. Moscow, Mysl. (1981 b). (in Russian).

3. Aristotle, Aristotle. Physics, transl. by V. P. Karpov, in Aristotle. Writings. In 4 vol., Vol. 3. Moscow, Mysl. (1981 c). (in Russian).

4. Aristotle, Aristotle. Metaphysics, transl. from Greek by P. D. Pervov and V. V. Rozanov, with comments by V. V. Rozanov (Moscow, Respublika, 2006). (in Russian).

5. Aristotle, Aristotle. Metaphysics, transl. from Ancient Greek, with foreword and comments by A.V. Markova (RIPOL Classic, Mosocw, 2018). (in Russian).

6. N.A. Artemenko, Heidegger's 'lost' manuscript: on the way to 'Being and Time' (St. Petersburg, 2012). (in Russian).

7. W.K. Benjamin, About the criticism of violence, Teaching about similarity. Media aesthetic works (Moscow, 2012) 65-99. (in Russian).

8. S.N. Borisov, V.P. Rimsky, Philosophical understanding of violence: meanings and connotations, Discourses of power, (Oryol State Institute of Culture, Oryol, OOO "Gorizont", 2015). (in Russian). 
9. A.V. Markov, Foreword, Aristotle. Metaphysics, transl. from Ancient Greek, foreword and comments by A. V. Markov (RIPOL Classic, Mosocw, 2018). (in Russian).

10. V.V. Rozanov, Collected Works. Literary exiles: H. N. Strakhov., K. N. Leontyev (Respublika, Moscow, 2001). (in Russian).

11. The Explanatory Dictionary of the Living Great Russian Language by Vladimir Dahl, The third, revised and enlarged edition, ed. by prof. Baudouin de Courtenay, 2, I-O. (SPb., M., 1905). (in Russian).

12. M. Heidegger, Phenomenological interpretations of Aristotle (Exposition of the hermeneutic situation), transl. from German, foreword, scientific ed., comp. of words by O. N. Artemenko (Humanitarian Academy Publishing House, St. Petersburg, 2012). (in Russian).

13. A.T. Yunusov, Powerless impossibility, Historical and Philosophical Yearbook, (The Institute of Philosophy of the Russian Academy of Sciences, Moscow, 2018), 33, 361385 (2018). (in Russian). 